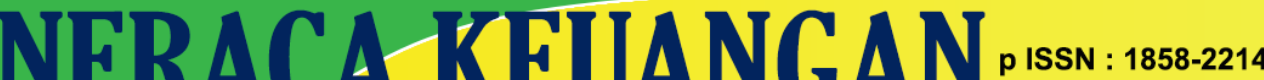

\section{Tendensi Kinerja dan Proyeksi Pertumbuhan Bisnis Asuransi di Masa Depan}

\author{
Neks Triani ${ }^{*}$, Ahmad Abbas², Sasmita Nabila Syahrir ${ }^{3}$ \\ 1,3Universitas Sembilanbelas November Kolaka, Indonesia \\ 2STAIN Majene, Indonesia \\ nekstriani1987@gmail.com
}

\begin{abstract}
This research aims to analyze the performance tendency within earnings reported by insurance firms in Indonesia and to project the growth of future insurance business. Sample of this research consisted of insurance firms listed on Indonesia Stock Exchange and financial statements utilized data with period of 2013-2018. The research variables were tested using the effect model of logistic significance. The result of this research pointed out that the mean of the performance of insurance firms deviates from actual earnings and of the business prospect is projected to have negative growth level for the coming years. Based on the effect test of significance, the result found that the earnings of insurance firms reported to deviate from actual earnings tends to weaken their business growth.
\end{abstract}

Keywords: Insurance business; earnings; growth.

\begin{abstract}
ABSTRAK
Penelitian ini bertujuan untuk menganalisis tendensi kinerja dalam laba yang dilaporkan oleh perusahaan asuransi di Indonesia dan memproyeksikan pertumbuhan bisnisnya di masa depan. Sampel penelitian ini terdiri dari perusahaan asuransi yang terdaftar di Bursa Efek Indonesia dan laporan keuangan menggunakan data periode 2013-2018. Variabel penelitian diuji menggunakan model efek signifikansi logistik. Temuan penelitian ini mengungkapkan bahwa rerata tendensi kinerja perusahaan asuransi menyimpang dari laba aktualnya dan rerata prospek bisnisnya diproyesikan mengalami laju pertumbuhan negatif di masa mendatang. Berdasarkan pada uji efek signifikansi, hasilnya menemukan bahwa laba perusahaan asuransi yang dilaporkan menyimpang cenderung melemahkan pertumbuhan bisnis.
\end{abstract}

Kata kunci: Bisnis Asuransi; Laba; Pertumbuhan.

\section{Pendahuluan}

Penciptaan produk baru dan lebih inovatif serta sesuai dengan kebutuhan nasabah adalah strategi pengembangan perusahaan asuransi agar masyarakat semakin tertarik menjadi nasabah. Inovasi produk meningkatkan pilihan dan pertimbangan nasabah dalam menggunakan jasa asuransi. Hal ini tentu mendorong aroma persaingan di industri keuangan. Pertumbuhan industri asuransi perlu dikembangkan agar semakin bersaing dengan industri perbankan. Setiadie (2019) menemukan bahwa struktur pasar asuransi di Indonesia masuk ke dalam jenis pasar persaingan sempurna yang ditandai dengan banyaknya perusahaan asuransi berkompetisi dan tanpa terdominasi di segmen industrinya. Sebelumnya Wartaekonomi (2018) telah memberitakan bahwa kesadaran asuransi masih rendah dan penetrasi industri asuransi masih di bawah 3\%. Perusahaan asuransi memiliki kapitalisasi pasar yang kurang besar sehingga masyarakat sebaiknya didorong oleh sedikitnya pemahaman terkait dengan jasa asuransi. Literasi masyarakat 
mengenai asuransi menjadi faktor penentu kemajuan bisnis asuransi. Setiawan (2013) mengungkapkan bahwa potensi pasar asuransi sangat besar sehingga perlu mendapat perhatian penting di mana kunci pertumbuhannya adalah pemahaman masyarakat mengenai asuransi.

Adanya tendensi pertumbuhan yang terjadi dari data yang ditunjukkan OJK berdasarkan hasil kinerja yang dilaporkan oleh industri asuransi mendorong penelitian ini perlu dilakukan. Terlebih lagi, informasi yang dilansir dalam Kompas (2020) yang mengungkapkan bahwa selama lima tahun terakhir kinerja industri asuransi berada pada kisaran positif sebagaimana dikaji dalam data OJK bahwa pertumbuhan asuransi dinilai terus meningkat sejak 2014 dan 2019. Berikut pertumbuhan asuransi dalam aset dan investasinya selama lima tahun terakhir.

Tabel 1. Total Aset dan Investasi Perasuransian di Indonesia

\begin{tabular}{lccccc}
\hline & \multicolumn{5}{c}{ Total (Triliun Rupiah) } \\
\cline { 2 - 5 } & 2015 & 2016 & 2017 & 2018 & 2019 \\
\hline Aset & 853,42 & $1.002,83$ & $1.176,97$ & $1.249,05$ & $1.325,74$ \\
\hline Investasi & 686,12 & 837,82 & $1.006,12$ & $1.067,44$ & $1.141,83$ \\
\hline \multicolumn{5}{c}{ Laju Pertumbuhan } \\
\cline { 2 - 5 } & $2014-2015$ & $2015-2016$ & $2016-2017$ & $2017-2018$ \\
\hline Aset & $17,5 \%$ & $17,3 \%$ & $6,12 \%$ & $6,13 \%$ \\
\hline Investasi & $22,0 \%$ & $20,1 \%$ & $6,09 \%$ & $6,96 \%$ \\
\hline
\end{tabular}

Sejauh pengetahuan riset mendalam yang dilakukan, penelitian terdahulu terkait dengan prospek pertumbuhan asuransi di masa depan pernah dikaji oleh Rahim (2013) dan Setiadie (2019). Pada penelitian Rahim (2013), tampak hanya mengkaji prospek pertumbuhan berdasarkan kajian literatur dengan mengungkapkan bahwa industri asuransi akan kuat dan sehat sehingga mampu memberikan kontribusi besar yang mendukung pertumbuhan ekonomi Indonesia pada lima tahun ke depannya jika hal tersebut diimbangi dengan pertumbuhan asuransi dengan baik. Memahami konsep penelitiannya, proyeksi pertumbuhan belum teruraikan empiris dan diuji secara kausalitas berdasarakan fenomena pertumbuhan yang terjadi. Sebaliknya, Setiadie (2019) memahami prospek industri asuransi di Indonesia mampu menguasai pangsa pasar yang lebih tinggi dan mencapai kinerja keuangan yang lebih baik sehingga pandanganya terhadap asuransi di masa depan menyediakan potensi dan prospek pertumbuhan yang besar. Berbeda halnya dengan penelitian Setiadie (2019) yang menyelidiki kemampuan pangsa pasar pada analisis konsentrasi industri asuransi, penelitian ini selanjutnya melakukan eksplorasi mendalam atas tendensi pertumbuhan kinerja yang terjadi pada perusahaan asuransi. Sesungguhnya, hal yang menarik dalam penelitian ini adalah sinyal kinerja yang tercatat oleh OJK di mana tampak memberikan optimisme terhadap prospek asuransi, sedangkan tingkat kepercayaan masyarakat terhadap jasa asuransi terkesan menurun apalagi semenjak adanya kasus gagal bayar asuransi Jiwasraya dan Bumi Putera kepada nasabahnya yang dinilai menurunkan kepercayaan publik terhadap prospek perusahaan asuransi ke depannya. Persepsi seseorang dalam memahami jasa asuransi memengaruhi keputusan berinvestasi (Ari dan Astiti, 2104), terlebih lagi ketika hal tersebut didukung oleh tingkat kepercayaan yang tinggi. Detikfinance (2020) mengungkapkan bahwa salah satu perusahaan yang dominan dikeluhkan oleh nasabahnya adalah perasuransian sehingga Yayasan Lembaga Konsumen Indonesia (YLKI) mencatat salah satu pengaduan terbesar konsumen adalah 
asuransi yang didominasi masalah klaim. Dalam kasus ini, bisnis asuransi telah tersirat mengalami pertumbuhan yang kurang produktif selama lima tahun terakhir ini.

Pada awal tahun 2020, Otoritas Jasa Keuangan (OJK) mencatat pertumbuhan industri asuransi masih positif dan memiliki daya tahan yang baik. Sebagaimana data yang dilansir OJK (2019), aset industri asuransi menunjukkan pertumbuhan positif 5.91 persen dari Rp 862 triliun pada 2018 menjadi Rp 913 triliun pada 2019. Lembaga pemerintah tersebut tampak menunjukkan bahwa perusahaan asuransi tetap memiliki prospek baik ke depan. Namun, apakah memang pertumbuhan asuransi akhir-akhir ini dinilai atraktif yang menunjukkan bahwa emiten asuransi mampu mengembangkan produk usahanya di kalangan masyarakat?. Berdasarkan data yang dirilis OJK sendiri, perekonomian Indonesia melalui ukuran PDB dari tahun 2017-2018 meningkat 9,20\% dari Rp 13.587,2 triliun menjadi Rp 14.837,4 triliun. Namun, rasio premi bruto terhadap PDB mengalami penurunan selama tahun 2017 sampai tahun 2018 dari 3\% menurun menjadi 2,92\%. Dengan demikian, kontribusi sector industri asuransi terhadap PDB menurun $0.08 \%$. Lebih lanjut, berdasarkan pada jumlah sahamnya bagi perusahaan asuransi go-public, perusahaan asuransi dinilai kurang menarik. Dikutip dalam CNBC Indonesia (2019), saham-saham asuransi dinilai kurang atraktif yang diakibatkan kurang likuid dan kecilnya kapitalisasi pasar. Tinjauan data awal, likuiditas perusahaan asuransi go-public pun tercatat mengalami penurunan setiap tahun selama lima tahun terakhir baik analisis rasio secara quick maupun cash.

Tabel 2. Likuiditas Perusahaan Asuransi Periode 2014-2018

\begin{tabular}{lccccc}
\hline & $\mathbf{2 0 1 4}$ & $\mathbf{2 0 1 5}$ & $\mathbf{2 0 1 6}$ & $\mathbf{2 0 1 7}$ & $\mathbf{2 0 1 8}$ \\
\hline Quick Ratio & 14.99 & 13.52 & 14.29 & 11.94 & 12.33 \\
\hline Cash Ratio & 2.85 & 3.28 & 2.45 & 1.71 & 1.24 \\
\hline & & Sumber. Data yang diolah dari OJK, 2020 & &
\end{tabular}

Sebagai hasil, tujuan substansi penelitian ini adalah untuk menganalisis tendensi kinerja dalam laba di perusahaan asuransi dan mengestimasi proyeksi pertumbuhannya di masa depan (Azis, 2019). Tujuan tersebut perlu dicapai agar mampu menyediakan temuan yang berkontribusi secara praktis pada otoritas yang berkepentingan dan secara teoretis pada perkembangan ilmu pengetahuan. Pertama, temuan penelitian ini dapat menjadi umpan balik (feed-back) dari kajian kinerja yang diyakini menyediakan distorsi bagi pertumbuhan indsutri non bank bahwa kinerja yang dialami oleh industri asuransi mengalami deviasi dari labanya sehingga hal ini menjadi sinyal dari otoritas terkait dalam pengawasan industri tersebut. Kedua, temuan penelitian ini berkontribusi teoretis bahwa prospek pertumbuhan bisnis asuransi menghubungkan kualitas dan ketidakpastian yang didasari pada teori sinyal.

Penelitian ini diuraikan ke dalam enam bagian. Bagian berikutnya adalah tinjauan pustaka dan pengembangan hipotesis. Bagian 3 adalah metode penelitian yang menguraikan data dan sampel serta analisis data. Bagian 4 adalah hasil dan bagian 5 adalah pembahasan. Simpulan diuraikan pada bagian 6 dengan menyediakan implikasi dan menyisakan studi lanjutan terkait penelitian ini.

\section{Landasan Teori dan Pengembangan Hipotesis \\ A. Asuransi: Konsep dan Perkembangan di Indonesia}

Industri asuransi telah menempatkan dirinya sebagai kebutuhan suplementari di masyarakat. Bisnis asuransi menjadi unsur penting dari risiko dan strategi manajemen bagi individu dan kelompok sosial. Asuransi adalah suatu bisnis jasa yang memiliki hubungan 
kontraktual di mana perusahaan asuransi sepakat dengan pihak tertanggung sebagai pemegang polis terhadap pembayaran premi dalam ketentuan moneter atas nama pihak yang tertanggung setelah klaim formal diajukan. Perusahaan asuransi adalah pihak yang berkewajiban memberikan jaminan sepenuhnya kepada nasabah jika terjadi sesuatu sesuai dengan perjanjian. Di Indonesia, industri mulai berkembang sejak 1980-an yang ditandainya dengan munculnya AIA Financial, Allianz, Avrist AXA Mandiri, dan Prudential. Bisnis asuransi mereka jalankan mulai tumbuh dan nasabah mulai merasakan layanan perlindungan dan investasinya. Produk asuransi tidak hanya terbatas pada jenis asuransi jiwa dan asuransi kesehatan, melainkan asuransi umum dengan jenis produk yang dapat dipilih di antaranya asuransi dana pendidikan, asuransi dana pensiun, asuransi kendaraan, dan asuransi properti. Penciptaan produk yang lebih inovatif mendorong masyarakat untuk mampu menjadi nasabahnya. Masyarakat sebagai calon nasabah akan mendapatkan layanan dalam bentuk perlindungan atas berbagai resiko dan kerugian yang akan menimpa mereka sewaktu-waktu, terlebih lagi mereka yang sedang memiliki usaha. Hal ini menimbulkan aroma persaiangan di industri asuransi. Mereka akan berlomba-lomba memberikan layanan sesuai dengan spesifikasi produk yang dihasilkan.

Berdasarkan data statisik OJK (2019), 151 emiten asuransi telah beroperasi dengan perusahaan asuransi go-public yang sudah terdaftar di BEI hingga tahun 2019 sebanyak 15 emiten.

Tabel 3. Perusahaan Asuransi Go-Public Selama Periode 2014-2018

No. Kode Perusahaan

Nama Perusahaan

\begin{tabular}{ccl}
\hline 1 & ABDA & Asuransi Bina Dana Arta Tbk \\
\hline 2 & AHAP & Asuransi Harta Aman Pratama Tbk \\
\hline 3 & AMAG & Asuransi Multi Artha Guna Tbk \\
\hline 4 & ASBI & Asuransi Bintang Tbk \\
\hline 5 & ASDM & Asuransi Daya Mitra Tbk \\
\hline 7 & ASJT & Asuransi Jaya Thania Tbk \\
\hline 8 & ASRM & Asuransi Ramayana Tbk \\
\hline 9 & LPGI & Lippo General Insurance Tbk \\
\hline 10 & MREI & Maskapai Reasuransi Indonesia Tbk \\
\hline 11 & PNIN & Paninvest Tbk d.h Panin Insurance Tbk \\
\hline 12 & ASMI & Asuransi Kresna Mitra Tbk d.h Asuransi Mitra Maparya \\
\hline 13 & JMAS & Asuransi Jiwa Syariah Jasa Mitra Abadi Tbk \\
\hline 14 & MTWI & Malacca Trust Wuwungan Insurance Tbk \\
\hline 15 & TUGU & Asuransi Tugu Pratama Indonesia Tbk \\
\hline
\end{tabular}

Sumber: Data yang diolah dari BEI, 2020

Perkembangan bisnis asuransi di Indonesia tercatat meningkat. Pertumbuhan asuransi umum dianggap memiliki pola pertumbuhan terbaik dan cepat tumbuh (Rasjid, 2013). Kondisi ini tentu diyakini oleh investor bahwa peran asuransi signifikan dalam mendukung terjadinya proses pembangunan nasional. Hal ini dapat dilihat dari prospek kontribusi perusahaan asuransi dalam memupuk dana jangka panjang dalam jumlah yang besar yang kemudian digunakan sebagai dana dalam pembangunan yang dilakukan oleh pemerintah. Jika kepercayaan mereka terhadap layanan asuransi tercipta dengan baik, bisnis asuransi akan menunjukkan perannya terhadap pertumbuhan nasional. Semakin banyak orang yang merasa 
ingin dilindungi terhadap berbagai macam resiko yang dihadapi di masa depan, semakin tercipta sinergi bisnis asuransi terhadap pertumbuhan ekonomi.

\section{B. Kecurangan Asuransi}

Bisnis asuransi tidak terlepas dari kecurangan yang dapat ditemukan di semua jenis asuransi. Kecurangan di industri asuransi dilakukan dengan membuat klaim fiktif atau cara-cara yang tidak jujur untuk keuntungan entitas (Gill dkk., 1994). Tiga prasyarat kecurangan adalah memiliki data pernyataan tertulis atau tidak tertulis yang menunjukkan adanya penyimpangan, ada kesengajaan dan tujuannya adalah keuntungan sepihak. Kecurangan asuransi bertujuan untuk mendapatkan keuntungan finansial dengan cara oportunistik. Tiga tipologi kecurangan asuransi yang diungkapkan dalam Viaene dan Dedene (2004), yaitu internal vs external, underwriting vs claim, dan soft vs hard. Pertama, kecurangan internal dilakukan orang internal seperti manajemen asuransi, agen, dan broker. Cara ini digambarkan dalam penjualan jasa asuransi tanpa lisensi yang benar hingga penggelapan dana asuransi, sedangkan kecurangan eksternal meliputi pelamar, pemegang polis, dan pengklaim yang seringkali dilakukan dalam kolusi dengan orang internal seperti agen atau pihak ketiga penyedia jasa dengan skema pemberian klaim palsu. Kedua tipologi kecurangan asuransi adalah underwriting vs claim. Kecurangan dapat dilakukan baik pada saat underwriting atau penjaminan maupun saat klaim. Skema kecurangan ini pada perolehan premi yang lebih rendah, atau terjadi risiko fiktif. Contoh lainnya, pemalsuan dokumen terhadap pihak tertanggung, misalnya pemegang polis dianggap sehat melalui keterangan dokter padahal sebenarnya dia memiliki penyakit turunan. Ketiga, kecurangan lunak dan keras. Kecurangan asuransi disebut lunak jika kondisinya pada agen asuransi dan karyawan perusahaan yang menggembungkan klaim (claim padding) dan salah mengartikan fakta tentang aplikasi asuransi, sedangkan hard atau keras jika kondisinya telah direncanakan sebelumnya melalui pengajuan klaim palsu misalnya rekayasa perampokan atau kecelakan, persengkongkolan yang melibatkan saksi, dan agen asuransi yang tidak jujur sengaja mengirimkan premi kepada perusahaan adalah tipikal kecurangan bersifat keras (hard). Secara keseluruhan, tipilogi kecurangan asuransi menggambarkan hal pertama adalah pemalsuan dokumen, misalnya pemalsuan identitas. Kedua adalah klaim yang telah direncanakan sebelumnya, misalnya rekayasa kecelakan mobil atau kesengajaan melukai diri sendiri. Ketiga mark-up nilai klaim, misalnya pihak ketiga dengan tagihan tindakan medis yang sebenarnya tidak perlu dicantumkan. Keempat adalah pemalsuan invoice. Dengan demikian, konsep kecurangan asuransi pada dasarnya tampak dalam kasus klaim yang secara sengaja ditambah atau dipalsukan.

\section{Pengembangan Hipotesis: Tendensi Kinerja, Pertumbuhan Bisnis, dan Teori Sinyal}

Kecurangan asuransi menjadi penipuan yang sengaja dilakukan oleh pihak tertanggung sebagai pemagang polis terhadap perusahaan atau agen asuransi dan sebaliknya dilakukan perusahaan atau agen asuransi kepada pihak tertanggung. Tujuan dilakukan kecurangan adalah keuntungan finansial secara sepihak. Klaim asuransi penipuan dapat menyebabkan kerugian yang besar bagi perusahaan asuransi yang mengakibatkan premi naik (Kirlidog dan Asuk, 2012; Hibbeln dkk., 2014). Beberapa sektor asuransi rentan terhadap kecurangan, yakni kesehatan, kompensasi kerja, dan asuransi mobil.

Lebih lanjut, tidak semua kecurangan asuransi dilakukan oleh pemegang polis. Di lain pihak, kecurangan dapat dilakukan agen asuransi, pihak rumah sakit atau dokter. Bisnis asuransi umumnya mampu melakukan praktik twisting dan churning, yaitu tindakan membujuk pemegang polis untuk mengubah spesifikasi polis yang ada atau mengganti polis yang lama menjadi polis baru. Agen asuransi rentan melakukan tindak kecurangan dengan cara pengalihan premi dan fee churning. Praktik ini tentu berdampak pada potensi kerugian nasabah yang akan menurunkan cash value sehingga polis tidak bernilai . Ketika kondisi ini terjadi, dana tambahan membayar polis baru memungkinkan tidak tersedia sehingga pemegang polis tidak mendapatkan cukup dana bahkan tidak ada dana sama sekali. Asimetri informasi mendasari keberadaan kecurangan. Dalam kontrak yang tersirat, akses informasi yang eksplisit biasanya 
terbatas pada satu pihak yang bertransaksi. Pihak penyedia informasi seringkali memiliki insentif yang jelas untuk melakukan asimetri informasi yang menandai kecurangan. Informasi tentang sifat risiko yang ditanggung oleh calon nasabah umumnya adalah informasi pribadi. Hal ini jelas menggambarkan salah saji atas informasi klaim. Suatu klaim dikatakan curang jika ada fakta material yang disembunyikan dan melakukan rekayasa, misalnya seorang nasabah tidak mengungkapkan penyakit yang diderita sudah ada dan memberikan keterangan yang menyatakan sehat saat mendaftar sebagai pemegang polis. Tujuan hal tersebut dilakukan adalah agar perusahaan cepat membayar polis nasabah. Cara lainnya yang paling umum terjadi adalah membuat klaim asuransi palsu hingga merekayasa nilai klaim yang tidak sesuai dengan nilai sesungguhnya.

Kecurangan asuransi tentu membawa kerugian baik perusahaan maupun nasabah. Pada pihak perusahaan, reputasi bisnisnya dianggap buruk karena turunnya stigma kepercayaan masyarakat, sedangkan pada pihak nasabah, kecurangan klaimnya akan dibawa ke ranah hukum dan dianggap sebagai tindak kriminal dan pada akhirnya nasabah tidak mendapatkan keuntungan sama sekali. Viaene dan Dedene (2004) menyatakan bahwa esensi kecurangan asuransi berada pada keberadaan asimetri informasi antar pihak transaksi dan pelanggaran prinsip itikad baik (utmost good faith) di mana tertanggung dan penanggung secara timbal balik harus berada pada kesepakatan asuransi dengan tidak menyembunyikan keterangan yang jelas dan benar yang dibutuhkan masing-masing pihak. Adanya asimetri informasi yang membuat klaim bisa ditolak. Nasabah juga harus memiliki pengetahuan yang tidak sifatnya oportunis dengan memberikan keterangan yang sesuai dengan informasi kesepakatan. Di sisi lain, masyarakat sebagai calon nasabah bisa mendapatkan sinyal yang akurat mengenai produk yang ditawarkan perusahaan. Ada banyak perusahaan asuransi yang menawarkan produk yang beragam dengan kualitas yang cenderung berbeda. Rekam jejak perusahaan adalah signal yang kuat menandai kinerja perusahaan. Tata kelola perusahaan asuransi dan prosepek perumbuhannya pun adalah sinyal pelengkap untuk menandai perusahaan asuransi dengan bisnisnya going concern.

Teori sinyal dapat digunakan dalam mengungkapkan informasi tingkat kualitas suatu produk. Dalam pandangan pengirim sinyal, perusahaan akan mengungkapkan kualitas produk atau jasanya sangat baik kepada para konsumennya (Abbas dkk., 2016), (Riani dan Hendrawan, 2020), dan (Riani, 2018). Perusahaan mengirim sinyal kepada investor untuk menunjukkan bahwa mereka lebih baik dari perusahaan yang lain dalam pasar sehingga para perusahaan dapat memperoleh investasi dan meningkatkan reputasinya. Ketidakmampuan pembeli untuk mengetahui kualitas produk sebelum melakukan pembelian adalah salah satu penentu perusahaan mengirimkan sinyal. Asimetri informasi kualitas produk perusahaan bisa saja terjadi jika perusahaan membuat kinerja terkesan berkualitas bagi pengguna eksternalnya. Sebagai hasil, masyarakat menilai perusahaan dengan baik melalui sinyal tersebut, apakah kualitas harga yang ditawarkan atau keuntungan klaim diperoleh nantinya oleh nasabah. Hal ini tentunya memberikan ketidakpastian apakah perusahaan asuransi mampu membayar klaim atau tidak. Begitupun dengan jejak rekam perusahaan dan kualitas kinerja yang dimiliki. Belum tentu hal demikian adalah bentuk sinyal terbaik untuk memilih jasa asuransi yang terbaik, tetapi tendensi laba adalah sinyal fundamental dalam menilai pertumbuhan bisnis asuransi. Laba yang dimiliki perusahaan asuransi menyediakan pertumbuhan kinerja yang berbeda. Kinerja yang labanya dianggap menyimpang akibat kecurangan yang diatur sebelumnya, mendorong penurunan pada level pertumbuhan kinerja asuransi.

Kecurangan pada dasarnya bersifat situasional yang bergantung pada tendensi stabilitas keuangan. Pada penelitiannya, Abbas (2017) menemukan bahwa semakin distres perusahaan, semakin terdorong perusahaan melakukan kecurangan. Saat perusahaan mengalami distres, mereka lebih besar tekanannya untuk melakukan kecurangan laba. Pada level pertumbuhannya, perusahaan asuransi yang melakukan kecurangan laba akan cenderung melemahkan pertumbuhannya sendiri di masa depan. Dengan demikian, hipotesis penelitian ini adalah 
"kinerja perusahaan asuransi yang labanya dilaporkan menyimpang cenderung melemahkan pertumbuhan bisnis".

\section{METODE PENELITIAN}

\section{A. Sampel dan Data}

Penelitian ini bersifat kuantitatif dengan menganalisis data laporan keuangan dan menguji hipotesis. Lingkungan penelitian ini adalah lingkungan riil (field setting) dengan unit analisisnya adalah laporan keuangan perusahaan asuransi termasuk asuransi jiwa dan asuransi umum. Data laporan keuangan dari perusahaan sampel dikumpulkan dengan metode dokumentasi. Sampel penelitian ini terdiri dari perusahaan asuransi yang terdaftar di BEI dari tahun 2013 hingga tahun 2018. Periode pengamatan selama lima tahun. Data tahun 2013 diperlukan untuk pengukuran kecurangan laba. Total sampel dalam penelitian ini sebanyak 10 perusahaan asuransi.

Tabel 4. Kriteria pengumpulan sampel

\begin{tabular}{lc}
\hline \multicolumn{1}{c}{ Kriteria } & Perusahaan \\
\hline Terdaftar berturut-turut dengan menerbitkan laporan keuangan 2013-2018 & 15 \\
Informasi data yang tidak lengkap termasuk laporan keuangan & $(5)$ \\
\hline Total & $\mathbf{1 0}$ \\
\hline Jumlah Pengamatan data & $\mathbf{5 0}$ \\
\hline
\end{tabular}

Sumber: Data diolah, 2020

\section{B. Definisi dan Pengukuran Variabel Penelitian}

Variabel penelitian ini adalah tendensi kinerja dalam laba sebagai variabel dependen dan level pertumbuhan asuransi sebagai variabel independen. Tendensi kinerja dalam laba adalah laba yang dilaporkan menyimpang dari laba aktualnya. Laba tersebut terindikasi curang. Sebagaimana yang diutilisasi oleh Abbas (2016), laba tersebut dianalisis menggunakan M-score. Laba tersebut terkesan berkualitas di pihak pengguna eksternal perusahaan. Standar untuk mengindikasikan laba yang menyimpang adalah kecurangan laba yang diproksikan dalam M-score dengan indeks lebih besar dari -2,22. Ukuran M-score dalam studi ini menggunakan formula dari Beneish (1999) dengan lima rasio yang telah termodifikasi karena beberapa ilmuwan (Kaur dkk., 2014; Mavengere, 2015; Paolone, 2014) telah mempertimbangkan hanya lima rasio dari M-Score yang menghasilkan signifikansi. Pada studi sebelumnya, Roxas (2011) telah mengkonfirmasi bahwa M-Score dengan lima rasio lebih mengidentifikasi secara akurat manipulasi laba daripada tujuh rasio. Jika M-Score di atas -2,22, perusahaan terindikasi melakukan penyimpangan laba dari kinerja aktualnya dan diberikan nilai 1 serta 0 sebaliknya. Adapun formula M-score disajikan sebagai berikut.

$$
\mathrm{M}=-6.065 \text { + 0.823 DSRI + 0.906 GMI + 0.593 AQI + 0.717 SGI + 0.107 DEP }
$$

Sebagai tambahan, indikator dan tolok ukur indeks kecurangan disajikan pada Tabel 5 sebagai berikut. 
Tabel 5. Indikator Modified M-Score

\begin{tabular}{|c|c|}
\hline Panel A. Ukuran indeks & \\
\hline DSRI (Days Sales in Receivables Index) & $=\frac{(\text { piutang bersih } / \text { penjualan })_{t}}{{\text { (piutang bersih } / \text { penjualan })_{t-1}}_{t}}$ \\
\hline GMI (Gross Margin Index) & $=\frac{(\text { Penjualan-HPP/Penjualan })_{t-1}}{(\text { Penjualan-HPP/Penjualan })_{t}}$ \\
\hline AQI (Asset Quality index) & $=\frac{1-\left((\text { Aset lancar } /(\text { aset tetap bersih }) / \text { total aset })_{\mathrm{t}}\right.}{1-((\text { Aset lancar/aset tetap bersih }) / \text { total aset }) \mathrm{t}-1}$ \\
\hline SGI (Sales Growth Index) & $=\frac{\text { Penjualan }}{t}_{\text {penjualan }}$ \\
\hline DEPI (Depreciation Index) & 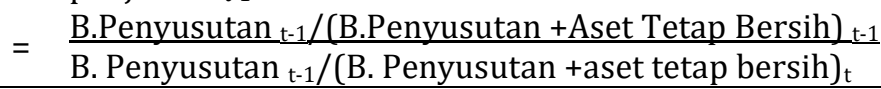 \\
\hline
\end{tabular}

Panel B. Tolok ukur

\begin{tabular}{lc}
\multicolumn{1}{c}{ Ratio } & Fraudster Mean Index \\
\hline DSRI (Days Sales in Receivables Index) & 1.46 \\
GMI (Gross Margin Index) & 1.19 \\
AQI (Asset Quality index) & 1.25 \\
SGI (Sales Growth Index) & 1.60 \\
DEPI (Depreciation Index) & 1.07 \\
\hline & Sumber: (Beneish,1999), (Warshavsky, 2015).
\end{tabular}

Pertumbuhan masa lalu dapat memberikan suatu informasi yang bernilai untuk mengestimasi pertumbuhan masa datang. Estimasi tingkat pertumbuhan kinerja bisnis asuransi diukur dengan menggunakan pertumbuhan asuransi dalam laba ditunjukkan sebagai berikut.

$$
\text { growt }_{t}=\frac{\mathrm{EBIT}_{\mathrm{t}}-\mathrm{EBIT}_{\mathrm{t}-1}}{\mathrm{EBIT}_{\mathrm{t}-1}}
$$

Growth adalah pertumbuhan kinerja dalam laba. EBIT $\mathrm{t}_{\mathrm{t}}$ adalah laba sebelum pajak penghasilan pada periode dasar $(\mathrm{t})$ dan EBIT $_{\mathrm{t}-1}$ adalah laba sebelum pajak penghasilan pada periode setahun sebelumnya periode dasar (t-1). Semakin besar laba yang diperoleh dari tahun ke tahun mencerminkan bahwa perusahaan memiliki kekuatan keuangan yang mampu tumbuh lebih besar dan dinilai sehat selama beroperasi dalam jangka waktu panjang.

Dalam mengukur suatu bisnis keuangan dapat dilihat dari indikator EPS (Maulani dan Riani, 2020). Pertumbuhan bisnis asuransi di masa depan diproyeksikan selama lima tahun mendatang dengan EPS odalah laba per saham tahun awal dan EPS ${ }_{n}$ adalah laba per saham tahun akhir yang hasilnya keduanya dikurangi satu.

$$
\text { Future Growth }=\left[\frac{E P S_{\mathrm{m}}}{\mathrm{EPSs}_{\sigma}}\right]^{\mathrm{n}}-1
$$

Di mana, Future Growth adalah proyeksi pertumbuhan mendatang, EPS adalah Earnings Per Share (Laba Per Saham), dan n adalah periode estimasi masa depan. Penelitian ini akan memproyeksikan lima tahun ke depan $(n=5)$ sebab periode pengamatan selama 5 tahun dari periode 2014-2018. 


\section{Uji Hipotesis}

Data dianalisis berdasarkan tujuan studi yang diolah statistik berdasarkan pengukuran variabel yang telah dihasilkan. Untuk menguji hipotesis digunakan regresi logistik. Model persamaan untuk menguji hipotesis adalah sebagai berikut.

$$
\text { EARNINGS }=\alpha+\beta_{1} \text { GROWTH }+\varepsilon
$$

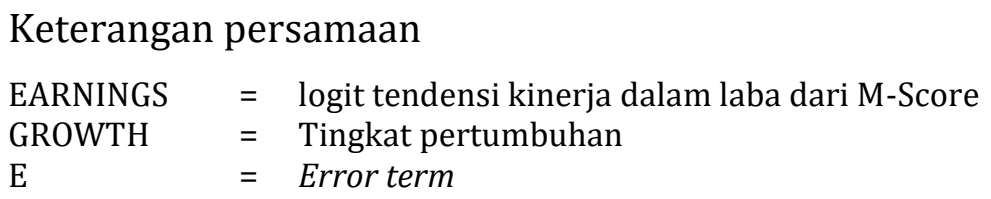

\section{Hasil dan Pembahasan}

\section{A. Temuan Penelitian}

\section{Deskripsi Variabel}

Tabel 7 menunjukkan deskripsi tendensi kinerja dalam laba perusahaan asuransi dari tahun 2014- 2018. Laba di atas nilai -2,22 yang menyimpang dari laba aktualnya sebanyak 13 laporan keuangan. Perusahaan yang memanipulasi labanya cenderung terjadi setiap tahun.

Tabel 7. Statistik Deskriptif Tendensi Kinerja

\begin{tabular}{|c|c|c|c|c|c|c|c|c|c|}
\hline & \multirow{2}{*}{ M-Score } & \multicolumn{5}{|c|}{ Financial Statment } & \multirow{2}{*}{ Logit } & \multirow{2}{*}{ Total } & \multirow{2}{*}{$\%$} \\
\hline & & 2014 & 2015 & 2016 & 2017 & 2018 & & & \\
\hline \multirow{3}{*}{ M-Score } & $>-2.22$ & 4 & 3 & 3 & 1 & 2 & 1 & 13 & 26 \\
\hline & $<-2.22$ & 6 & 7 & 7 & 9 & 8 & 0 & 37 & 74 \\
\hline & & 10 & 10 & 10 & 10 & 10 & & 50 & 100 \\
\hline
\end{tabular}

Sumber. Data diolah, 2020

Setelah diperoleh 13 laporan keuangan yang terindikasi mengandung penyimpangan laba, studi ini menganalisis masing-masing indeks penyimpangan laba tersebut yang dianggap curang.

Tabel 8. Statistik deskriptif indeks kecurangan laba

\begin{tabular}{|c|c|c|}
\hline Ratio & $\begin{array}{c}\text { Fraudsters Mean } \\
\text { Index }\end{array}$ & $\mathbf{N}$ \\
\hline DSRI(Days Sales in Receivables Index) & 1.46 & 3 \\
\hline GMI (Gross Margin Index) & 1.19 & 9 \\
\hline AQI (Asset Quality index) & 1.25 & 0 \\
\hline SGI (Sales Growth Index) & 1.60 & 1 \\
\hline DEPI (Depreciation Index) & 1.07 & 2 \\
\hline
\end{tabular}

Sumber. Data diolah, 2020 
Rata-rata perusahaan sampel yang menghasilkan M-score di atas -2,22 memiliki indeks di atas indeks standar kecurangan (fraudsters mean index). Tiga perusahaan sampel dengan laporan keuangan yang menghasilkan indeks DSRI di atas 1.46. Indeks tersebut mengindikasikan bahwa terjadi kenaikan yang tidak sebanding dalam piutang (terutama piutang premi) terhadap pendapatan. Di samping itu, sembilan laporan keuangan perusahaan sampel menunjukkan indeks marjin kotor yang sangat tinggi di atas indeks 1.19. Indeks ini mengartikan bahwa perusahaan telah mengalami penurunan marjin kotor secara aktual. Besarnya tekanan untuk meningkatkan kinerja keuangannya mendorong mereka melakukan pengaturan laba melalui indeks marjin laba. Pada indeks SGI, hanya ada satu perusahaan sampel yang berupaya mendorong pertumbuhan pendapatannya. Kondisinya mengindikasikan bahwa perusahaan sangat depresif untuk mencari cara dalam meningkatkan kinerjanya, misalnya menggeser pengakuan pendapatan. Jika ada kenaikan abnormal dalam penjualan, hal ini memungkinkan karena perusahaan telah menggeser pengakuan pendapatan ke periode berikutnya. Pada indeks penyusutan (DEPI), dua laporan keuangan perusahaan sampel telah mengalter estimasi umur ekonomisnya. Untuk keseluruhan, hanya indeks kualitas aset yang tetap terjaga. Tidak ada reduksi kualitas aset pada perusahaan sampel. (Warshavsky, 2012), menyatakan bahwa kualitas aset yang lebih besar 1,0 atau mendekati indeks kecurangan mengindikasikan bahwa perusahaan meningkatkan penangguhan biaya atau aset tak berwujudnya, dan terdorong manipulasi laba. Indeks kualitas aset tetap terjaga pada perusahaan sampel karena tidak terindikasi indeks yang abnormal.

Pada variabel tingkat pertumbuhan, rerata pertumbuhan perusahaan asuransi mengalami pertumbuhan negatif sebesar -0,08 yang menunjukkan bahwa tingkat pertumbuhan dalam laba tumbuh ke arah negatif sebesar $0.08 \%$ dalam 5 tahun terakhir. Selama periode tersebut, pertumbuhannya terendah berada pada tingkat $-6 \%$ dan tertinggi pada tingkat $3 \%$.

Tabel 9. Statistik Deskriptif Tingkat Pertumbuhan

\begin{tabular}{lccccr}
\hline \multicolumn{1}{c}{ Variabel } & N & Mean & Min & Max & Std Dev \\
\hline Tingkat Pertumbuhan (GROWTH) & 50 & -0.08 & -6.00 & 3.13 & 0.989 \\
Negative Growth & 16 & & & & \\
Positive Growth & 34 & & & & \\
& & & & & \\
\end{tabular}

Sumber. Data yang diolah, 2020

\section{Hasil Analisis Data}

Pada perusahaan asuransi yang menjadi sampel, ada 13 laporan keuangan yang terindikasi menyimpang dari laba aktualnya dengan rerata sebesar $26 \%$ dari total laporan keuangan sampel dan rerata tingkat pertumbuhan berada pada nilai negative 0.08\%. Untuk memastikan hasil keduanya bahwa tendensi kinerja (yang labanya menyimpang dari aktualnya) menyediakan pengaruh terhadap penurunan tingkat pertumbuhan, penelitian ini selanjutnya perlu menguji efek signifikansi. 
Tabel 10. Hasil Analisis Data

\begin{tabular}{|c|c|c|c|c|c|c|c|}
\hline \multicolumn{8}{|c|}{ Panel A. Hasil Regresi Logistik } \\
\hline \multirow{9}{*}{$\begin{array}{l}\text { Constant } \\
\text { GROWTH }\end{array}$} & \multirow{4}{*}{ Variable } & \multirow{2}{*}{\multicolumn{2}{|c|}{$\begin{array}{l}\text { Expected } \\
\text { Sign }\end{array}$}} & \multicolumn{4}{|c|}{ Model } \\
\hline & & & & B & Wald & Sig. & $\operatorname{Exp}(B)$ \\
\hline & & & & 4.029 & 2.550 & 0.110 & 56.201 \\
\hline & & $\mathrm{H} 1$ & - & -1.442 & 0.440 & 0.001 & 0.236 \\
\hline & Overall percentage & $76 \%$ & & & & & \\
\hline & -2 Log Likehood Blo & & & & & 57.306 & \\
\hline & -2 Log Likehood Blo & & & & & 50.759 & \\
\hline & Hosmer and Lemesl & & & & & 0.302 & \\
\hline & Nagelkerke R Squar & & & & & 0.180 & \\
\hline \multicolumn{8}{|c|}{$\begin{array}{l}\text { Earnings adalah variabel dependen yang diproksikan dari m-score } \\
\text { Growth adalah variabel independen yang diproksikan dari EPS }\end{array}$} \\
\hline \multicolumn{5}{|c|}{ Panel B. Hasil Proyeksi Pertumbuhan Masa Depan } & Mean & Max & Min \\
\hline \multicolumn{5}{|c|}{ Future Growth (EPS) } & -0.078 & 0.08 & -0.33 \\
\hline
\end{tabular}

Pada Tabel 10, regresi logistik menyediakan hasil uji hipotesis yang menunjukkan bahwa variabel GROWTH menghasilkan koefisien -1.442 dengan signifikansi pada level 0.001. Koefisien dengan arah negatif mengungkapkan bahwa kinerja dalam laba mendorong pertumbuhan bisnis asuransi ke arah negatif. Laba yang dimaksud adalah logit dari laba yang menyimpang dari laba aktualnya yang diberikan nilai 1 . Hasil ini mengartikan bahwa perusahaan dengan kinerja yang menyimpang dari laba aktualnya cenderung melemahkan level pertumbuhan bisnisnya. Dengan demikian, hipotesis yang dibangun dalam penelitian ini diterima yang menyatakan bahwa perusahaan asuransi dengan laba yang menyimpang dari nilai aktualnya melemahkan level pertumbuhan bisnis.

Selanjutnya, bagaimana proyeksi pertumbuhan perusahaan bisnis asuransi saat kinerja menyimpang dari laba aktual?. Penelitian ini kemudian melakukan estimasi pertumbuhan bisnis asuransi di masa depan yang diproyeksikan selama lima tahun mendatang. Berdasarkan panel B pada tabel 10 di atas, proyeksi pertumbuhan kinerja menghasilkan rerata -0.078. Hasil ini menunjukkan bahwa estimasi kinerja EPS perusahaan asuransi di masa depan mengalami rerata pertumbuhan negatif. Kemudian penelitian ini mengamati sampel individual. Berdasarkan hasil pengamatan pada sampel individual, ada dua perusahaan asuransi dengan indeks M-Scorenya di bawah 2.22 atau dinilai tidak menyimpang dari laba aktualnya. Hasil proyeksi kedua perusahaan tersebut berada pada nilai positif.

\section{Analisis Tambahan}

Di samping earnings, total aset umumnya menjadi tolok ukur proksi pertumbuhan kinerja perusahaan. Penelitian ini melakukan uji tambahan dengan menyubtitusi proksi earnings menjadi total aset. Tujuannya adalah agar analisis data dalam penelitian ini 
menyediakan konsistensi hasil yang mendorong temuan yang akurat dan inferensi yang reliable.

$$
\text { growth } h_{T A}=\frac{\mathrm{TA}_{\mathrm{t}}-\mathrm{TA}_{\mathrm{t}-1}}{\mathrm{TA}_{\mathrm{t}-1}}
$$

Di mana growth adalah pertumbuhan kinerja dalam aset dan TA adalah total aset. $\mathrm{TA}_{\mathrm{t}}$ adalah total aset pada periode dasar $(\mathrm{t})$ dan $\mathrm{TA}_{\mathrm{t}-1}$ adalah total aset pada periode setahun sebelumnya periode dasar ( $\mathrm{t}-1)$. Selanjutnya, proyeksi pertumbuhan bisnis dapat diestimasi dengan menggunakan future growth (Abbas, 2019), (Riani dan Maulani, 2020). Proyeksi tingkat pertumbuhan masa depan bisnis asuransi melalui rumus sebagai berikut.

$$
\text { Future Growth }=\left[\frac{\text { Aset }_{\mathrm{n}}}{\text { Aset }_{\mathrm{o}}}\right]^{\text {in }}-1
$$

\begin{tabular}{|c|c|c|c|c|c|c|c|}
\hline \multicolumn{8}{|c|}{ Panel A. Hasil Regresi Logistik } \\
\hline & \multirow{4}{*}{ Variable } & \multirow{2}{*}{\multicolumn{2}{|c|}{$\begin{array}{l}\text { Expected } \\
\text { Sign }\end{array}$}} & \multicolumn{4}{|c|}{ Model } \\
\hline & & & & B & Wald & Sig. & $\operatorname{Exp}(B)$ \\
\hline \multirow{7}{*}{$\begin{array}{l}\text { Constant } \\
\text { GROWTH }\end{array}$} & & & & 1.527 & 0.583 & 0.110 & 4.606 \\
\hline & & H1 & - & -1.251 & 9.317 & 0.001 & 0.286 \\
\hline & Overall percentage & $76 \%$ & & & & & \\
\hline & \multicolumn{4}{|c|}{-2 Log Likehood Block 0} & \multicolumn{3}{|c|}{57.306} \\
\hline & \multicolumn{4}{|c|}{-2 Log Likehood Block 1} & \multicolumn{3}{|c|}{56.347} \\
\hline & \multicolumn{4}{|c|}{ Hosmer and Lemeshow } & \multicolumn{3}{|c|}{0.900} \\
\hline & \multicolumn{4}{|c|}{ Nagelkerke R Square } & \multicolumn{3}{|c|}{0.028} \\
\hline
\end{tabular}

Tabel 11. Hasil Analisis Data

Earnings adalah variabel dependen yang diproksikan dari m-score Growth adalah variabel independen yang diproksikan dari total aset

\begin{tabular}{cccc}
\hline Panel B. Hasil Proyeksi Pertumbuhan Masa Depan & Mean & Max & Min \\
\hline Future Growth (Total Aset) & -0.004 & 0.22 & -0.71 \\
\hline
\end{tabular}

Sumber. Data diolah, 2020

Pada Tabel 11, variable GROWTH yang diproksikan dari total aset menghasilkan koefisien -1.251 dengan signifikansi pada level 0.001. Koefisien dengan arah negatif menunjukkan hasil yang sama dengan variabel GROWTH yang diproksikan dari EPS. Kondisi ini semakin membuktikan hasil yang konsisten bahwa tendensi kinerja yang labanya menyimpang mendorong pertumbuhan kinerja bisnis asuransi ke arah negatif. Dengan demikian, hasil yang sama diperoleh pada proyeksi pertumbuhan masa depan yang disubtitusi ke dalam total aset. Level pertumbuhan masa depan melalui total aset menunjukkan rerata -0.004 . Kondisi ini menunjukkan konsistensi temuan bahwa estimasi kinerja di masa depan baik melalui proksi EPS maupun total aset mengalami rerata pertumbuhan negatif.

\section{B. Pembahasan}


Kualitas kinerja perusahaan asuransi dapat diidentifikasi melalui tendensi laba yang mengalami distorsi. Laba tersebut terkesan berkualitas dalam laporan keuangan sehingga kelihatan menarik bagi pengguna eksternal. Teori sinyal digunakan dalam penelitian ini untuk melihat kecenderungan laba yang menyimpang dari indeks aktualnya. Dengan utilisasi M-score yang memproksikan pada indeks DSRI, SGI, GMI, DEPI, dan AQI, penelitian ini menemukan tendensi kinerja yang menyimpang pada indeks pendapatan terhadap piutang dan indeks marjin laba kotor. Perusahaan telah mengalami penurunan marjin kotor secara aktual. Besarnya tekanan untuk meningkatkan kinerja keuangannya mendorong mereka melakukan kecurangan laba. Pendapatan underwriting yang cenderung menurun seiring dengan kenaikan beban klaim yang rentan terjadi sehingga mendorong pengaturan melalui indeks marjin laba kotor. Pada indeks DSRI, perusahaan cenderung membuat perubahan kebijakan premi sehingga terjadi kenaikan yang tidak sebanding piutang terhadap pendapatan.

Penelitian ini selanjutnya melakukan uji efek signifikansi dengan menganalisis efek yang ditimbulkan saat kinerja mengalami penyimpangan dari laba aktualnya terhadap level pertumbuhan. Hasilnya menyediakan efek negatif terhadap level pertumbuhan bisnis asuransi. Pada hipotesis sebelumnya, rumusan menyatakan bahwa kinerja perusahaan asuransi yang labanya dilaporkan menyimpang cenderung melemahkan pertumbuhan bisnis. Hasil dari uji efek signifikansi menunjukkan bahwa variabel tendensi kinerja menyediakan hasil negatif terhadap variabel level pertumbuhan. Dengan demikian, hipotesis diterima. Hal ini dapat dijelaskan bahwa kinerja yang labanya menyimpang menyediakan pengaruh terhadap penurunan tingkat pertumbuhan. Selanjutnya, penelitian ini memproyeksi pertumbuhan asuransi lima tahun ke depan. Hasilnya adalah bahwa perusahaan asuransi menyediakan rerata negatif. Pertumbuhan asuransi di masa depan berada pada level negatif baik melalui pertumbuhan earnings maupun pertumbuhan aset. Hasil ini menjadi sinyal bagi stakeholders bahwa prospek pertumbuhan di masa depan kurang menguntungkan sebab pertumbuhannya tampak menurun bahkan mengalami rerata negatif.

Pertumbuhan melemah ketika kinerja mengalami deviasi atau penyimpangan. Teori sinyal mengelaborasi temuan tersebut. Asimetri informasi kualitas kinerja perusahaan bisa saja terjadi jika perusahaan membuat kinerja terkesan berkualitas bagi pengguna eksternalnya. Perusahaan cenderung tampak memberikan kualitas produk dan kinerja yang baik beberapa periode, tetapi hal tersebut belum tentu menjadi cara terbaik untuk mempertahankan kelangsungan usaha di masa depan. Justru kinerja bisnis akan terproyeksikan menurun hingga mencapai kondisi distres. Sebagai tambahan, kinerja dalam laba adalah sinyal fundamental dalam menilai pertumbuhan bisnis asuransi. Laba yang dimiliki perusahaan asuransi menyediakan pertumbuhan kinerja yang berbeda. Tendensi laba yang dimaksud jika dianggap menyimpang akibat kecurangan laba yang diatur sebelumnya. Kondisinya terbukti signifikan mendorong penurunan pada level pertumbuhan kinerja asuransi. Terlebih lagi, jika perusahaan mulai mengalami distres, perusahaan memperoleh tekanan yang lebih besar untuk melakukan kecurangan laba sebagaimana yang ditemukan oleh Abbas (2017). Oleh karena itu, besarnya tekanan untuk meningkatkan kinerja keuangan mendorong perusahaan asuransi melakukan kecurangan laba.

Temuan penelitian ini tampaknya berbeda dengan hasil penelitian dari Setiadie (2019) yang meyakini sebelumnya bahwa kinerja keuangan di masa depan akan lebih baik dan menyediakan potensi dan prospek pertumbuhan yang besar di masa depan. Temuan dari hasil penelitian ini sebaliknya cenderung mengestimasi prospek bisnis 
asuransi tidak akan menguntungkan dan tidak menggambarkan rerata pertumbuhan yang baik di masa depan. Penelitian ini memahami bahwa perbedaan terjadi karena penelitian sebelumnya cenderung menggunakan analisis konsentrasi industri yang mengandalkan konsep pangsa pasar di bawah Structure-Conduct-Performance (SCP), padahal pertumbuhan kinerja asuransi sebaiknya dianalisis mendalam pola indeks kinerja yang berada pada analisis kinerja keuangan. Sesungguhnya, analisis konsentrasi industri melihat pola persaingan yang terjadi antar industri saja.

\section{Kesimpulan}

Kinerja perusahaan asuransi mengalami penyimpangan secara aktual. Tendensinya cenderung terjadi pada perusahaan yang telah mengalami penurunan marjin laba kotor secara aktual dan terjadi kenaikan yang tidak sebanding dalam piutang premi terhadap pendapatan asuransi. Perusahaan asuransi yang terindikasi labanya menyimpang dari aktualnya cenderung melemahkan pertumbuhan bisnisnya sendiri. Analisis lanjutan dilakukan dalam penelitian ini dengan memproyeksikan pertumbuhannya lima tahun mendatang. Hasilnya, rerata pertumbuhan perusahaan asuransi berada pada nilai negatif baik melalui pertumbuhan earnings maupun aset. Dengan demikian, prospek pertumbuhan perusahaan asuransi ke depannya kurang menguntungkan.

Temuan penelitian ini menjadi respon terhadap otoritas yang berkepentingan. Memahami prospek pertumbuhan bisnis asuransi di masa depan kurang menguntungkan, perusahaan asuransi sebaiknya meningkatkan kualitas kinerjanya dengan baik. Hal yang tidak bisa dipungkiri, OJK sebaiknya meningkatkan kualitas pengaturan dan memperkuat pengawasan yang kemudian diimbangi peningkatan literasi pemahaman asuransi. Di sisi lain, penelitian ini bukan sengaja mendorong investor untuk menghindari investasi lebih dalam bisnis asuransi yang prospeknya dinilai kurang menguntungkan di masa depan, melainkan kewaspadaan dan kehatihatian memilih emiten asuransi. Asuransi dengan entitas besar dan memiliki kemampuan laba yang besar bukan selamanya menjadi pilihan yang menarik bagi berinvestasi. Kinerja dalama laba dengan proyeksi pertumbuhan masa depan yang cukup baik cenderung tercermin dari jumlah penjualan, total aset, serta investasi yang stabil dan tampak menawarkan harga premi yang terjangkau.

Penelitian ini terlebih dahulu menyadari bahwa sampel yang digunakan masih sedikit, maka analisis tambahan sengaja didesain untuk memperkuat temuan. Studi lanjutan perlu dilakukan dengan diferensiasi jumlah sampel yang besar yang kemudian mengutilisasi teknik data mining pada klaim asuransi dalam jumlah besar. Hubungan level pertumbuhan dan literasi mengenai pemahaman asuransi juga menjadi sebuah tantangan yang disediakan dalam penelitian ini bagi studi lanjutan ke depannya. Dengan demikian, para ilmuwan ke depannya akan terdorong untuk merevisit penelitian ini sebagai bagian dari kajian pelengkap dalam membuat model penelitian lanjutan.

\section{Referensi}

Abbas, A., Habbe, A.H., \& Pontoh, G.T (2015). Kualitas Pengungkapan Segmen dan Hubungannya dengan Biaya Modal Ekuitas. Simposium Nasional Akuntansi XVII, 127. 
Abbas, A. (2017). Earnings Fraud and Financial Stability. Asia Pasific Fraud Journal, Vol. 2 No. 1: 117-134.

Abbas, A. (2019). Analisis Laporan Keuangan Perbankan Syariah. Parepare: Dirah.

Ari, I.A.G.R.P \& P. Astiti. (2014). Peran Persepsi Individu terhadap Asuransi dan Model Kepercayaan Kesehatan dalam Pengambilan Keputusan Menggunakan Asuransi Jiwa. Jurnal Psikologi Udayana, Vol. 1, No. 2: 381-388.

Azis, A. D. (2019). KEMAMPUAN PASAR DALAM MEMPREDIKSI LABA MASA MENDATANG MELALUI KEBIJAKAN DIVIDEN KAS PERUSAHAAN. Neraca Keuangan: Jurnal Ilmiah Akuntansi dan Keuangan, 14(2).

Beneish, M.D. (1999). The Detection of Earnings Manipulation. Financial Analyst Journal, 1: 24-26.

Detikfinance. (2020). Aduan Masyarakat Terbanyak di 2019 Soal Pinjol Hingga Asuransi, diakses 15 Februari 2020, https://m.detik.com/finance/berita-ekonomi-bisnis/d48581/aduan-masyaraka-terbanyak-di-2019-soal-pinjol-hingga-asuransi.

Gill, K.M., K.A, Woelley, \& M. Goll. (1994). Insurance Fraud: the Business as a Victim. In M. Gill (Ed.) Crime at Work, 1: 78-82. Leicester: Perpeituity Press.

Hibbeln, M., J.L., Jenkins, C.Schneider, J.S, Valacich, \& M. Weinmann. (2014). Investigating the Effect of Insurance Fraud on Mouse Usage in Human-Computer Interactions. Thirty Fifth International Conference on Information Systems, 1-16.

CNCB. (2019). Pertumbuhan Industri Asuransi Lesu, Apa Penyebabnya?, Diakses 10 Februari 2020, https://www.cnbcindonesia.com/investment/2019070814381121-83378/pertumbuhan-industri-asuransi-lesu-apa-penyebabnya.

Kirlidog, M \& C. Asuk. (2012). A Fraud Detection Approach with Data Mining in Health Insurance. Procedia-Social and Behavioral Sciences, 62: 989-994.

Kompas. (2020). Lima Tahun Terakhir, Kinerja Industri Asuransi Positif, diakses 5 Februari

2020,

https://amp.kompas.com/money/read/2020/01/21/172614726/lima-tahunterakhir-kinerja-industri-asuransi-positif.

Maulani, D., \& Riani, D. (2021). Pengaruh Inflasi, Suku Bunga dan Rasio Keuangan terhadap Harga Saham. Oikonomia: Jurnal Manajemen, 17(2), 84-96.

OJK. (2018). Statistik Perasuransian 2018. Laporan Otoritas Jasa Keuangan, diakses 10 Juni 2020, www.ojk.go.id.

OJK. (2019). Statistik Asuransi Indonesia Desember 2019, diakses 15 Juli 2019, www.ojk.go.id.

Rahim, H. (2013). Optimisme Pertumbuhan Asuransi Indonesia; Proyeksi Perkembangan Lima Tahun (2014-2018). Jurnal Asuransi Manajemen dan Resiko, Vol. 1, No. 2: 1-21.

Rasjid, Ibnu. (2013). Pola dan Pertumbuhan Perusahaan Asuransi di Indonesia. Majalah Ekonomi dan Komputer, 2: 94-106.

Riani, D. (2018). Penilaian Efisiensi Dengan Data Envelopment Analysis Pada Bank Umum Syariah (BUSN Devisa dan Non Devisa). Neraca Keuangan: Jurnal Ilmiah Akuntansi Dan Keuangan, 13(1). 
Riani, D., \& Hendrawan, S. (2020). DATA ENVELOPMENT ANALYSIS (DEA): PERBANDINGAN EFISIENSI BANK SYARIAH DAN BANK KONVENSIONAL PERIODE 2014-2018. Neraca Keuangan: Jurnal Ilmiah Akuntansi dan Keuangan, 15(2), 25-41.

Riani, D., \& Maulani, D. (2020). Determinan Efisiensi Perbankan Syariah: Two Stage Data Envelopment Analysis. PROSIDING LPPM UIKA BOGOR.

Roxas, M.L. (2011). Financial Statement Fraud Detection Using Ration and Digital Analysis. Journal of Leadership, Accountability, and Ethics, Vol. 8, No. 4:56-66.

Setiadie, H. (2019), Analisis Kompetisi dan Prospek Industri Asuransi di Indonesia: Studi pada Industri Asuransi Jiwa dan Asuransi Umum di Indonesia, Tesis: Universitas Gadjah Mada.

Setiawan, S. (2013). Prospek dan Daya Saing Sektor Perasuransian Indonesia di Tengah Tantangan Integrasi Jasa Keuangan ASEAN. Jakarta: Naga Media.

Viaene, S \& G. Dedene. (2004). Insurance Fraud: Issues and Challenges. The Geneva Papers on Risk and Insurance, Vol. 29, No. 2: 313-333.

Wartaekonomi. (2018). Menilik Pertumbuhan Industri Asuransi di Indonesia, diakses 10 Februari 2020, https://www.wartaekonomi.co.id/read207639/menilikpertumbuhan-industri-asuransi-di-indonesia.

Warshavsky, M.S. (2015). Forensic Tools \& Techniques. Marryland Association of CPS's, $\begin{array}{llll}\text { diakses } & 10 & \text { Februari 2020, }\end{array}$ http://macpamedia.org/media/downloads/2015FVS/Warshavsky PPT1pp.pdf. 